\title{
Main drivers of tobacco consumption among adolescents: the case of Kyrgyzstan
}

\section{Zamira Oskonbaeva ${ }^{1}$}

1 Kyrgyz-Turkish Manas University, Department of Economics, Kyrgyzstan, e-mail: zamira.oskonbaeva@manas.edu.kg

\begin{abstract}
Tobacco smoking among youth is a global concern. Tobacco's dangers and the probability of addiction are often underestimated by young people. Preventing tobacco consumption among youth is critical since tobacco-related illnesses will take away the lives of considerable number of young people who continue to smoke into adulthood. Youth are more vulnerable to nicotine (Goriounova and Mansvelder 2012) and may become addicted to it quicker than adults may. Even though they decide to quit in a few years, three out of four teen smokers continue to smoke into adulthood due to nicotine addiction.
\end{abstract}

The main purpose of this study is to investigate the tobacco consumption of adolescents in Kyrgyzstan. For this aim, a schoolbased survey of students aged 13-15 years was utilized. Global Youth Tobacco Survey was conducted in 2019 by Centres for Disease Control and Prevention. The questionnaire consists of 56 questions. This survey was conducted in order to get knowledge about adolescents' attitudes about smoking.

The Heckman selection model was employed for the empirical analysis. In the light of obtained results, it can be concluded that the main drivers of tobacco consumption among adolescents are age, gender, amount of spending money, parental smoking status, among others. The results indicate that tobacco consumption is higher among males. Parents' smoking habit leads to a higher probability of an adolescent to become a smoker in the future.

The outcomes from this study may provide some insights into the policies implemented to lessen smoking among adolescents not only for Kyrgyzstan but also for other countrie

Keywords: Tobacco Consumption, Heckman Selection Model, Kyrgyzstan, Survey, Adolescents, Cross Section Data, Microeconometrics

JEL Codes: $C 1$, C52, I12, C83, C81

Citation: OSKONBAEVA Z, (2021). Main Drivers of Tobacco Consumption Among Adolescents: The Case of Kyrgyzstan Journal of Applied Microeconometrics (JAME). 1(1), 28-38 DOI: 10.53753/jame.1.1.03 


\section{INTRODUCTION}

Each year eight million people lost their lives because of smoking. In other words, one death occurs every five seconds (Martin 2020). It costs the world 2 trillion dollars due to rising health related costs and productivity loss (UNDP 2019). It is considered that fifty percent of today's children and youth who consume tobacco will not live until the age of 70. Every consumed tobacco takes 11 minutes off your life (Martin 2020).

Tobacco smoking among young people is a serious problem both developed and developing countries have to manage. According to estimates, more than 10\% of 13-15 years old students consume tobacco in some way. Furthermore, about 3 out of 4 school smokers will become adult smokers (US Department of Health and Human Services 2014).

Borracci and Mulassi (2015) reported that smoking even one cigarette a month during adolescence was strongly linked to adult tobacco use, suggesting that many adult smokers could be prevented if smoking was not commenced during adolescence. It implies that preventing adolescents from smoking is critical since it has a long term impact. This finding emphasizes that by preventing the tobacco consumption of young people, the health status of the whole nations can be improved. Young people are known to be more likely to be influenced by those around them. Tobacco usage is portrayed as a societal norm in films, music videos, and advertisements leading younger generation to smoke.

Youth's smoking behavior is affected by the tobacco industry's advertising and marketing campaigns to a greater degree compared to the adult smoking behavior (Pollay et al 1996). Almost nine out of ten smokers that start smoking by the age of 18 , and more than $80 \%$ of young smokers select tobacco brands which are the top three most heavily marketed brands (US Department of Health and Human Services 2017).

Additionally, they are more likely to become a smoker if their parents or peers do smoke. These findings underline once more that preventing tobacco consumption among adolescents is a worldwide concern requiring the attention from both families and governments.

As in other countries, youth smoking is widespread in Kyrgyzstan. Kyrgyzstan is a landlocked country in the Central Asia with a population of 6.5 million people. The prevalence of the current tobacco use ( $\%$ of adults) is $27.9 \%$ (World Bank 2020). Figure 1 shows that the prevalence of daily smoking among people aged 10 years old and above is considerably high among the Central Asian countries.

Figure 1. Prevalence of Daily Smoking Aged 10 Years Old and Above (1990 to 2016)

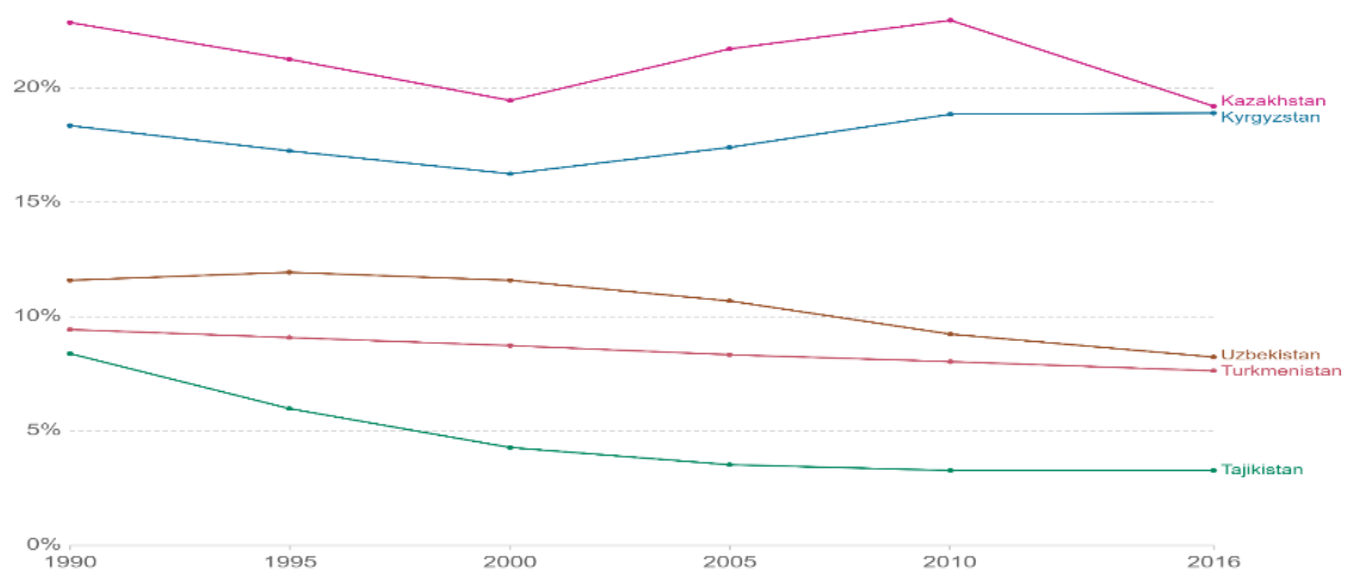

Source: IHME, Global Burden of Disease, Our World in Data.

There exist gender differences in tobacco consumption. The prevalence of tobacco consumption among men is 52.5 $\%$, while this figure is approximately $3.4 \%$ for females. More than 4500 people die as a result of tobacco-related 
diseases annually in Kyrgyzstan (The Tobacco Atlas 2021). After heart disease, smoking-related lung disease comes as the second leading cause of death in Kyrgyzstan. Figure 2 below presents premature deaths attributed to smoking per 100,000 individuals. As can be observed from the figure, in all the Central Asian countries smoking related death rate is still high (except Uzbekistan).

Figure 2. Smoking Death Rate (1990-2017)

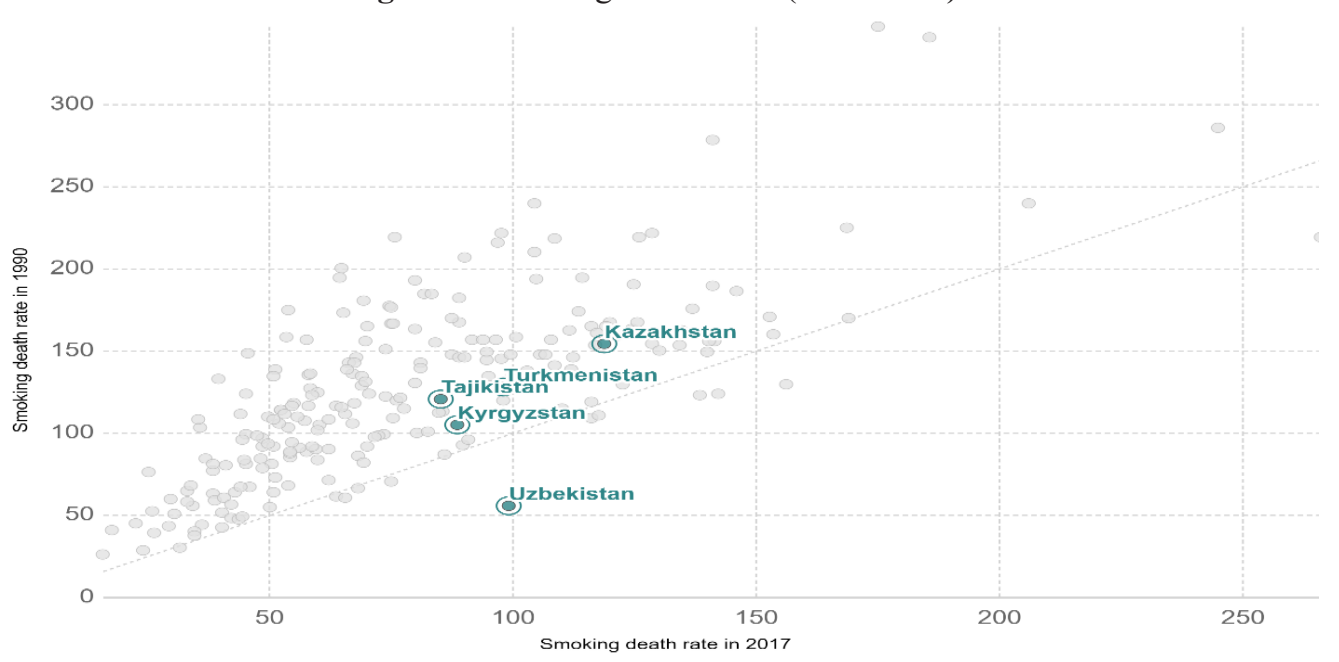

Source: IHME, Global Burden of Disease, Our World in Data.

In Kyrgyzstan 16 women lose their lives due to tobacco consumption every week (The Tobacco Atlas 2021). About 2500 boys and 700 girls aged 10-14 years old are using tobacco daily. This indicates that smoking consumption is widely spread among adolescents, too (The Tobacco Atlas 2021). In Kyrgyzstan the economic cost of smoking is 6450 million som including both direct and indirect costs associated with healthcare spending and reduced productivity as a result of premature mortality and morbidity (The Tobacco Atlas 2021).

Widespread tobacco consumption among adolescents is a sign of a great threat to the health of the total population. The findings of research conducted in 2017 demonstrate that there are many tobacco points of sale (POS) near the schools in Kyrgyzstan (Kyrgyzstan Tiny Targets Report 2018). The results indicate that in these POS $88.9 \%$ of all tobacco products were displayed in front of children; $61.1 \%$ of all tobacco were displayed near sweets or toys, and in $87.3 \%$ of POS cigarettes are sold by piece (Kyrgyzstan Tiny Targets Report 2018). All these factors may contribute to the spread of cigarette consumption among school pupils. Since children are our future, not only families but governments as a whole should care about children's health. All necessary steps should be taken in order to prevent the spread of smoking among adolescents.

The main purpose of this study is to explore the main drivers of tobacco consumption among adolescents in Kyrgyzstan. In the empirical analysis, GYTS (Global Youth Tobacco Survey 2019) data on tobacco consumption were employed. The Heckman (1979) selection model was employed to investigate the main drivers of smoking among adolescents. The main advantage of this specification is that it takes zero consumption observations into consideration. This is the case when the sample contains observations in which the dependent variable is zero and this feature is particularly notable among addictive goods like cigarettes (Yen 2005). Selection and outcome equations are estimated in the empirical analysis. Selection equation considers the main factors which affects adolescents' decision to smoke, while outcome equation determines the factors that influence the amount of tobacco used.

The remainder of this study is structured as follows. A brief review of the literature is presented in the second section. Third section is devoted to the dataset and variables utilized in the empirical analysis. Methodology and obtained findings are discussed in the fourth section. Discussion and conclusion are presented in the last section. 


\section{LITERATURE}

The main contributing factors of smoking have been elaborated by researchers in the context of different countries. They focus on the factors associated with the current status of tobacco use among adolescents, adults, men and women separately. The findings indicate that the main drivers of tobacco consumption are age (Alasqah et al. 2021), gender (Granja et al. 2020), marital status (Alkan and Abar 2020), parental smoking status, education level (Klosterhalfen et al. 2021), socioeconomic status, living environment (Aho et al. 2018), social factors (Lazurenko et el. 2020), among others.

Below is a brief overview of previous studies grouped by factors that promote smoking.

The previous literature suggests that the social factors are crucial factors which have an impact on smoking behaviour of youths. Bonilha et al. (2013) concluded that social smoking is a more important motivator for adolescents compared to adult smokers. Lazurenko et al. (2020) investigated the main motives for smoking behaviour among students studying at college in Russia. According to their findings, smoking is considered as a tool of communication and integration for college students. In other words, social factors were found to be significant in explaining tobacco smoking.

Another group of studies concluded that lifestyle factors were main drivers of smoking. Mutlu Çamoğlu (2013) in case of Turkey revealed that the stress of urban life and working environment is important factor influencing smoking. Alkan and Abar (2020) investigated the factors of influencing tobacco smoking in Turkey. Logistic and probit regression results unveiled that age, gender, education, marital status, fruit consumption, exposure to tobacco smoke at home, and frequent of alcohol consumption were found as determining factors of smoking. La Fauci et al. (2021) investigated the impact of individual habits, lifestyles, the presence of smokers in the family and the use of electronic cigarettes on tobacco consumption among adults in Italy. The results indicate that if there is one smoker in the family it increases the likelihood of being a current smoker three times higher. Alcohol and coffee consumption, being unemployed and being a student were found to be contributing factors to smoking. Alkan and Ünver (2021) explored the main determinants of female's smoking behaviour. Logistic regression results indicated that age, education level, working conditions, income, general health status, psychosocial support conditions, and alcohol consumption were statistically significant variables in explaining smoking behaviour. Guimarães et al. (2021) revealed that the absence of religious beliefs, unhealthy eating habits, illicit drug abuse, and self-rated health were the main drivers of smoking behaviour of students in Brazil. Jain et al. (2021) reported that smokeless tobacco use (i.e. loose leaf, plug, twist, snus, or snuff) often leads to the increased consumption of cigarettes, e-cigarettes, and alcohol employing multivariable logistic regression models for the United States.

The results of other studies indicated that living environment was more critical in spreading tobacco consumption. De Vries et al. (2003) explored the impact of parents' and friends' smoking behaviours the on smoking status of adolescents in six European countries. By employing multiple regression model they investigated predictors of smoking. The results indicated that parents' and friends' smoking behaviours were found to be statistically significant in explaining the tobacco consumption of adolescents. Aho et al. (2018) investigated factors affecting smoking behaviour of Finnish vocational school students. Multinomial regression model results suggested that mother's smoking status was more influential on adolescent daily tobacco consumption.

The findings of other studies emphasized that age and gender were major contributing factors to smoking. Granja et al. (2020) reported that the habit of smoking was more prevalent among male students studying at a Brazilian private university. Alasgah et al. (2021) explored smoking predictors among adolescents using Saudi Arabian cross-sectional survey data. Their results revealed that age, gender, and academic performance were main drivers of smoking. Similarly, a study for Germany by Klosterhalfen et al. (2021) revealed that the water pipe consumption was associated with older age, male, migration background, lower educational level, and current smoking status.

A group of researches focusing on the ICT (Information and Communication Technologies) use and concluded that cell phone use and video games were the main motives for smoking among adolescents. Piola et al. (2021) explored the relationship between cell phone use and tobacco consumption among adolescents with different physical activity levels. Logistic regression results indicated that the cell phone use was a risk factor for alcohol and tobacco consumption. Garcia-Garcia et al. (2021) assessed the relationship between video games and tobacco 
smoking among adolescents living in Spain. They concluded that there was a positive association between those two variables.

According to the results of other researches, it can be concluded that income was a major influencing factor of smoking. Donfouet et al. (2021) assessed the determinants of smoking use in Kenya. They concluded that poorer households were more impacted by tobacco use than richer households were. Using Korean data, Kim and Park (2021) investigated the impact of tobacco price on smoking behaviour. The findings indicated that cigarette price increases had no statistically significant impact on smoking cessation among smokers.

Advertising was found to be a contributing factor to smoking in studies conducted by Ali et al. (2020) and IbarraSalazar et al. (2020). Ali et al. (2020) explored the impact of e-cigarette advertisement exposure on e-cigarette and cigarette consumption among US adults. They found that e-cigarette advertising increased the amount of tobacco and e-cigarette used among adults of all ages. In the same way, Ibarra-Salazar et al. (2020) employing Dynamic Least Squares model (DOLS) with quarterly data (1994-2015), in the context of Mexico have revealed that health warnings reduced tobacco consumption.

According to the findings obtained by Escobedo et al. (1998), Fergusson et al. (2003), Rohde et al. (2004), McManus et al. (2010) and Nkomo et al. (2021) mental health behaviours predict the initiative to smoke.

In the case of Kyrgyzstan there existed a study conducted by Vinnikov et al. (2006) which were devoted to the analysing of the prevalence of smoking among medical students. Authors concluded that the prevalence were higher among men compared to women. Also the results unveiled that the likelihood of consuming alcohol was higher among smokers.

Literature review has shown that regression models (Aho et al. 2018; Ibarra-Salazar et al. 2020), logistic and probit regression models (Alkan and Abar 2020; Jain et al. 2021) and Heckman selection model (Madden 2008; Mutlu Çamoğlu 2013; Nkomo et al. 2021) are widely adopted in examining smoking behaviour of adolescents.

As can be seen from the above discussed literature, the main motives for smoking have been elaborated from different aspects. The findings differ due to the methodology used and the dataset utilized. In the context of Kyrgyzstan, smoking behaviour of adolescents have not been a focus of the researchers, yet. Thus, I hope that this study adds value to the growing body of literature through identifying the main motives for smoking among adolescents.

\section{VARIABLES AND DATA}

This paper employs the Global Youth Tobacco Survey (GYTS) dataset to investigate the major drivers of tobacco consumption among adolescents in Kyrgyzstan. The dataset is a cross-sectional survey of adolescents aged 13 to 15 years. This survey is conducted by the Centres for Disease Control and Prevention during January/August 2019. The funding for the GYTS was provided by the Canadian Public Health Association, National Cancer Institute, United Nations Children Emergency Fund, and the World Health Organization-Tobacco Free Initiative.

The variables incorporated in the model are age, gender, amount of spending money, parental smoking behaviour, experimentation with any form of smoked tobacco products other than cigarettes, own something with tobacco brand on it, student's opinion on the cost of cigarette, and using smokeless tobacco/nasway. Nasway can be defined as a smokeless tobacco for oral use, which is widely consumed mainly in Central Asian countries (WHO 2018).

In the first stage, the dependent variable is 1 if the adolescent spends on cigarettes, 0 otherwise. In the second stage, the dependent variable is a number of days spent smoking during the last month. The total sample size is 6145 observations (individuals) with an average age of approximately 14 years with a majority of males (50.7\%). $14.1 \%$ of adolescents reported that they have ever tried with cigarette smoking. The definitions of variables in the study are presented in Table 1 . 
Table 1. Definitions of Variables Used in the Model

\begin{tabular}{|c|c|}
\hline Variables & Definitions \\
\hline \multicolumn{2}{|l|}{ Dependent variables } \\
\hline Smoking participation & 1 if the youth spends on cigarettes, 0 otherwise. \\
\hline $\begin{array}{l}\text { Number of days spent smoking during } \\
\text { past month }\end{array}$ & $\begin{array}{l}\text { A categorical variable that is categorized into following groups; } 1-2 \text { days, } 3-5 \text { days, } 6-9 \text { days, } \\
10-19 \text { days, } 20-29 \text { days, } 30 \text { days. }\end{array}$ \\
\hline \multicolumn{2}{|l|}{ Explanatory variables } \\
\hline Age & Years \\
\hline Gender & $1=$ male, 0 otherwise \\
\hline Amount of spending money & $\begin{array}{l}\text { A categorical variable that is categorized into seven groups, do not have any spending money, } \\
\text { less than } 20 \text { som, } 20-50 \text { som, } 51-100 \text { som, 101-200, 201-500, and more than } 500 \text { som. }\end{array}$ \\
\hline Using smokeless tobacco/nasway & $1=$ yes, 0 otherwise. \\
\hline $\begin{array}{l}\text { Own something with tobacco brand on it } \\
\text { ( } \mathrm{t} \text { shirt, pen, backpack) }\end{array}$ & $1=$ yes, 0 otherwise. \\
\hline Student's opinion on the cost of cigarette & $\begin{array}{l}\text { A pack of } 20 \text { cigarettes costs: } 20-40 \text { som, } 41-50 \text { som, } 51-60 \text { som, } 61-70 \text { som, } 71-100 \text { som, } \\
101-150 \text { som, more than } 150 \text { som. }\end{array}$ \\
\hline $\begin{array}{l}\text { Experimentation with any form of } \\
\text { smoked tobacco products other than } \\
\text { cigarettes }\end{array}$ & $1=$ yes, 0 otherwise. \\
\hline Parental smoking status & 1 if fathers smoke, 0 otherwise. \\
\hline
\end{tabular}

\section{METHODOLOGY AND FINDINGS}

In order to determine the major drivers of tobacco consumption among adolescents Heckman selection model is applied. In case of the existence of sample selection, the observed data do not represent a random sample of the population. In other words, the data omitted in the sample does not respond to a random selection process (Zuzana et al. 2018). Therefore, a conventional analysis that only considers complete cases would produce biased results. This study employs the sample selection model developed by James Joseph Heckman (1979) is employed to address the potential sample selection bias and to obtain unbiased estimates of smoking behaviour.

Several studies elaborating smoking behavior of individuals employed this procedure (Madden 2008; Nkomo et al. 2021; Mutlu Çamoğlu 2013). The Heckman two-step procedure estimates two different models (probit and OLS regression). The main advantage of this procedure is that it allows for the possibility that factors affecting the probability of smoking and the amount of cigarette consumption are not the same. This procedure provides two estimated equations. The first one is a selection equation concentrating on the participation into the sample. The second one is an outcome equation which estimates smoking intensity.

In other words, the Heckman model estimates the determinants of adolescents being a smoker and the amounts of tobacco consumed. The selection equation should contain at least one variable that is not incorporated into the outcome equation (Wooldridge 2002). The main advantageous of this procedure is that it can be employed to correct for a sample selection bias (Heckman 1979).

This procedure has been applied in wage equation estimations for the first time. Then it has been employed in other fields effectively (Farrell and Walker 1999; Madden 2008). In this procedure all zeros are determined at the first stage. That is, once an adolescent decides to smoke, we will observe positive values.

Following Heckman (1979), the outcome equation can be specified as below:

$Y_{i}^{*}=X_{1 i} B_{1}+u_{i}$

and selection equation can be written as below:

$$
Z_{i}^{*}=X_{2 i} B_{2}+\varepsilon_{i} \quad(\mathrm{i}=1,2, \ldots \ldots 1)
$$


where $\mathrm{Xji}$ is a vector of exogenous variables, $\mathrm{B}_{\mathrm{j}}$ is a vector of parameters, $\varepsilon_{i}$ and $u_{i}$ error terms of two equations. It is assumed that they are jointly normally distributed.

$\left(u_{i}, \varepsilon_{i}\right) \sim N I D\left(0,\left[\begin{array}{cc}\sigma_{\varepsilon i}^{2} & \rho \sigma_{u i} \\ \rho \sigma_{u i} & 1\end{array}\right]\right)$

$u_{i}$ and $\varepsilon_{i} \sim N\left(0,0, \sigma^{2} u_{i}, \sigma^{2} \varepsilon_{i}, \rho \sigma_{u i}\right)$, bivariate normal distribution with expectation zero, $\sigma^{2} u_{i}$ and $\sigma^{2} \varepsilon_{i}$ denote variances, respectively and $\rho \sigma_{u i}$ is a covariance. The term $\sigma_{u i}$ is the standard deviation of $u_{i}$ and $\rho$ stands for the correlation between $u_{i}$ and $\varepsilon_{i}$ (Greene 2003).

The results of Heckman model are displayed in Table 3.

Table 3. Heckman Model

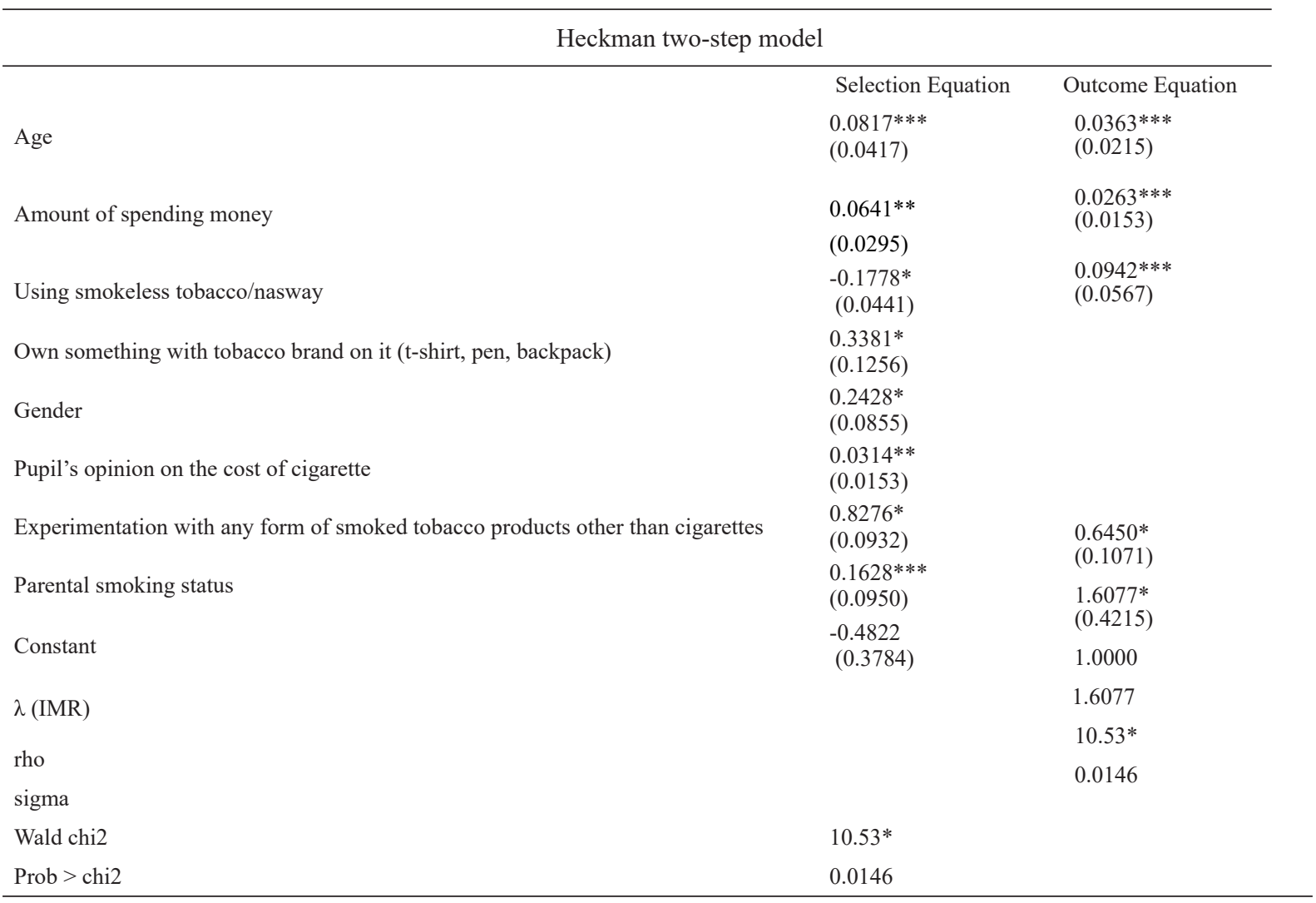

$* * *, * *, *$ denotes statistically significance at $10 \%, 5 \%$ and $1 \%$, respectively. Standard errors are reported in parentheses.

The Wald test results show the goodness of fit for the model. First column indicates that age, gender, amount of spending money, parental smoking status, experimentation with any form of smoked tobacco products other than cigarettes, own something with tobacco brand on it, using smokeless tobacco/nasway, pupil's opinion on the cost of cigarette have significant effects on the selection equation; showing that they are important drivers of being a smoker.

Any experimentation with tobacco products leads to a higher probability of an adolescent to become a smoker. Table 3 shows that this factor is the biggest contributor to adolescents initiating smoking. Another influencing factor to smoking participation is parental smoking status. The results indicate that adolescents, whose fathers smoke, are more likely to become a smoker compared to adolescents, whose fathers do not smoke. The coefficient of age is positive and significant. It implies that the probability of adolescents to become a smoker is rising with age. An adolescents' likelihood of smoking increased in line with the level of pocket money received from parents. Having something with tobacco logo (t-shirt, pen, backpack) increases the probability of smoking participation. The coefficient of smokeless tobacco/nasway using is found to be negative in the selection equation. It implies that the consumption of smokeless tobacco nasway is decreasing with the probability of being a cigarette smoker. 
The positive coefficient in the outcome equation signifies that after becoming a smoker consumption of nasway increases the amount of tobacco used. According to the GYTS, 5.1\% of adolescents aged $13-15$ (7.6\% of boys and $2.9 \%$ of girls) in Kyrgyzstan consume smokeless tobacco (WHO 2018).

Moreover, the results indicate that boys are more likely to become a smoker compared to girls. In the outcome equation, all variables are found to be statistically significant. In other words, the coefficient of age indicates that the amount of tobacco consumption increases with age. The amount of pocket money increases the level of tobacco consumption. The coefficient of pupil's opinion on the cost of cigarette is found to be positive. This suggests that the cost of tobacco does not prevent pupils from being a smoker. This can be explained partly by the fact that there are many POS around the school in which cigarettes are sold by piece. Study conducted by Robertson et al. (2016) focusing on the impact of POS concluded that the chances of having attempted smoking were around 1.6 times higher among children and young people who were regularly exposed to point-of-sale cigarette promotion comparing to those who were less frequently exposed. Furthermore, chance of being vulnerable to potential smoking were 1.3 times higher among never smokers who were often exposed to point-of-sale tobacco compared with those who were less frequently exposed.

The inverse of Mills' ratio (IMR) is also found to be statistically significant. In other words, it indicates that applied procedure is appropriate for estimation. In order to control for sample selection, the ordinary-least-square regression adds on the inverse Mills' ratio (IMR) calculated from the linear predictions of the probit model as an additional explanatory variable. Rho is the correlation coefficient of the error terms from the selection and the outcome equation. Sigma is the estimator of the standard error of the residual in the regression equation. The coefficients are different from zero. It implies that OLS is biased and there is need to use a selection-bias correction model.

These results are parallel to the findings of previous studies conducted by Klosterhalfen et al. (2021), De Vries et al. (2003), Granja et al. (2020) and Alasqah et al. (2021).

\section{CONCLUSION}

The main objective of this study is to determine the main drivers of tobacco consumption among adolescents using the data collected from Kyrgyzstan. In the empirical analysis, the survey data provided by the GYTS was employed. In order to explore the factors that influence tobacco use, a procedure developed by Heckman (1979) was utilized. The empirical model is appropriate since it takes observations with zero tobacco consumption into the consideration.

In terms of the parental smoking status, results illustrate that fathers smoking behaviour contributes significantly to the decision to smoke or not (selection equation). Turning to the amount of pocket money, results indicate that it contributes significantly to both the likelihood of being a smoker and amount of tobacco used. Moreover, it can be concluded that there are gender differences in tobacco consumption. In other words, findings signify that male adolescents smoke more than female adolescents do. Outcomes report that there is a positive relationship between age and tobacco smoking. Age increases the likelihood of being a smoker (in selection equation) and the amount of tobacco used (in outcome equation).

The findings obtained from this study may provide some insights into the policies implemented to decrease smoking among adolescents in Kyrgyzstan. Smoking bans in public spaces, anti-smoking advertising campaigns being implemented in order to minimize tobacco consumption. Policies and interventions that aim to prevent and reduce adolescents' tobacco consumption should be developed and applied. Enormous efforts should be undertaken by not only families but also governments as a whole to reduce tobacco smoking among adolescents.

\section{Funding}

The author declares that this study has no financial support. 


\section{REFERENCES}

- AHO, H., KOIVISTO, A.M., PAAVILAINEN, E. and JORONEN, K. (2018). Parental Involvement and Adolescent Smoking in Vocational Setting in Finland. Health Promotion International, 3(5), 846-857. https://doi.org/10.1093/ heapro/dax027

- AlASQAH, I., MAHMUD, I., EAST, L. and USHER, K. (2021). Prevalence of Smoking and Smoking Predictors among Adolescents in Qassim, Saudi Arabia: Does the Healthy City Programme Make Any Difference? Journal of Public Health, 1-8.

- ALKAN, Ö. and ABAR, H. (2020). Determination of Factors Influencing Tobacco Consumption in Turkey Using Categorical Data Analyses. Archives of Environmental \& Occupational Health. 75(1), 27-35.

- ALKAN, Ö. and ÜNVER, Ş. (2021). Tobacco Smoke Exposure among Women in Turkey and Determinants. Journal of Substance Use, 1-7.

- ALI, F. R. M., DAVE, D. M., COLMAN, G. J., WANG, X., SAFFER, H., MARYNAK, K. L., DENCH, D. and GROSSMAN, M. (2021). Association of e-Cigarette Advertising with e-Cigarette and Cigarette Use among US Adults. Addiction, 116, 1212-1223. https://doi.org/10.1111/add.15281.

- BONILHA, A.G., DE SOUZA, E.S.T., SICCHIERI, M.P., ACHCAR, J.A., CRIPPA, J.A.S. and BADDINI-MARTINEZ, J. (2013). A Motivational Profile for Smoking among Adolescents. Journal of Addiction Medicine, 7(6), 439-446. doi:10.1097/01.ADM.0000434987.76599.c0.

- BORRACCI, R.A. and MULASSI, A.H. (2015). Tobacco Use During Adolescence May Predict Smoking During Adulthood: Simulation-Based Research. Arch Argent Pediatr, 113, 106-12.

- CENTERS FOR DISEASE CONTROL AND PREVENTION (CDC) (2019). Ministry of Education and Science (Kyrgyzstan), Ministry of Health (Kyrgyzstan), World Health Organization (WHO). Kyrgyzstan Global Youth Tobacco Survey 2019. Atlanta, United States of America: Centers for Disease Control and Prevention (CDC).

- DE VRIES, H., ENGELS, R., KREMERS, S., WETZELS, J. and MUDDE, A. (2003). Parents' and Friends' Smoking Status as Predictors of Smoking Onset: Findings from Six European Countries. Health Education Research. 18(5), 627-636, https://doi.org/10.1093/her/cyg032

- DONFOUET, H.P.P., MOHAMED, S.F. and MALIN, E. (2021). Socioeconomic Inequality in Tobacco Use in Kenya: A Concentration Analysis. Int J Health Econ Manag. https://doi.org/10.1007/s10754-020-09292-0

- ESCOBEDO, L.G., REDDY, M. and GIOVINO, G.A. (1998). The relationship between Depressive Symptoms and Cigarette Smoking in US Adolescents. Addiction, 93, 433-40.

- FARRELL, L. and WALKER, I. (1999). The Welfare Effects of Lotto: Evidence from the UK. Journal of Public Economics, 72(1), 99-120.

- FERGUSSON, D.M., GOODWIN, R.D. and HORWOOD, L.J. (2003). Major Depression and Cigarette Smoking: Results of a 21-Year Longitudinal Study. Psychological Medicine, 33(8), 1357-1367.

- GARCÍA-GARCÍA, E., MARTÍNEZ-GIMENO, M. L., BENÍTEZ-ANDRADES, J. A., MIRANDA-GÓMEZ, J., ZAPATA-CORNEJO, E. D. and ESCOBAR-AGUILAR, G. (2021). Substance Use and Addictive Behavior in Spanish Adolescents in Secondary School. Healthcare (Basel, Switzerland), 9(2), 186. https://doi.org/10.3390/ healthcare9020186

- GORIOUNOVA, N. A. and MANSVELDER, H. D. (2012). Short- and Long-Term Consequences of Nicotine Exposure During Adolescence for Prefrontal Cortex Neuronal Network Function. Cold Spring Harbor Perspectives in Medicine, 2(12), a012120. https://doi.org/10.1101/cshperspect.a012120

- GRANJA, G. L., LACERDA-SANTOS, J. T., DE MOURA BRILHANTE, D., DE SOUSA NÓBREGA, I., GRANVILLE-GARCIA, A. F., JUNIOR, A. D. F. C. and DOS SANTOS, J. A. (2020). Smoking and Alcohol Consumption among University Students of the Healthcare Area. Journal of Public Health. 28(1), 45-52.

- GREENE, W.H. (2003). Econometric Analysis. 4th edn. Upper Saddle River, NJ: Prentice Hall. 
- Guimarães, N. S., DE PAUlA, W., DE AGUiAR, A. S. and MEIRELES, A. L. (2021). Absence of Religious Beliefs, Unhealthy Eating Habits, Illicit Drug Abuse, and Self-Rated Health is Associated with Alcohol and Tobacco Use among College Students—Padu Study. Journal of Public Health, 1-9.

- GUTEMA, B.T., CHUKA, A., AYELE, G., ESTIFAONS, W., MELKETSEDIK, Z.A., TARIKU, E.Z., ZERDO, Z., BAHARU, A. and MEGERSA, N.D. (2021). Tobacco Use and Associated Factors among Adults Reside in Arba Minch Health and Demographic Surveillance Site, Southern Ethiopia: A Cross-Sectional Study. BMC Public Health, $21,441$. https://doi.org/10.1186/s12889-021-10479-4

- HECKMAN, J. (1979). Sample Selection Bias as a Specification Error. Econometrica 45, 153-161.

- IBARRA-SALAZAR, J., ROMERO-ROJAS, J. C. and AYALA-GAYTÁN, E. (2020). The Duration Effect of Pictorial Health Warnings on Tobacco Consumption in Mexico. Global Public Health. 1-19.

- IHME, (Institute for Health Metrics and Evaluation) Global Burden of Disease (2021). http://www.healthdata.org/ $\mathrm{gbd} / 2019$ Accessed on April 2, 2021.

- JAIN, V., AL-RIFAI, M., NADERI, S., BAROLIA, R., IQBAL, S., TAJ, M. and VIRANI, S. S. (2021). Association of Smokeless Tobacco Use with the Use of Other Illicit Drugs in the United States. The American Journal of Medicine, 134(1), e15-e19.

- KIM, D. and PARK, H. (2021). Effects of a Cigarette Price Increase on the Smoking Behavior of Smokers and Nonsmokers. American Journal of Health Behavior. 45(2), 205-215.

- KlOSterhalfen, S., KOTZ, D., KUNTZ, B., ZEIHER, J. and STARKER, A. (2020). Waterpipe Use among Adolescents in Germany: Prevalence, Associated Consumer Characteristics, and Trends (German Health Interview and Examination Survey for Children and Adolescents, KiGGS). International Journal of Environmental Research and Public Health, 17(21). DOI: 10.3390/ijerph17217740

- KYRGYZSTAN TINY TARGETS REPORT (2018). Report prepared for the Campaign for Tobacco-Free Kids by Grassriots Inc Kyrgyzstan Tiny Targets Report: Tobacco Advertisement, Sales, Product Displays, and Purchase Incentives Around Primary, and Secondary Schools. Toronto, ON; -Washington, DC 2017. Accessed on April 14, 2021.

- LA FAUCI, V., MONDELlO, S., SQUERI, R., ALESSI, V., GENOVESE, C., LAUDANI, N. and CATTARUZZA, M.S. (2021). Family, Lifestyles and New and Old Type of Smoking in Young Adults: Insights from an Italian MultipleCenter Study. Ann Ig. 33(2), 131-140. doi: 10.7416/ai.2021.2419. PMID: 33570085.

- LAZURENKO, N.V., PODPORINOVA, N.N., POLENOVA, M.E., KOVALCHUK, O.V. and KOROLEVA, K.I. (2020). Social Factors of Spreading of Tobacco Smoking Among College Students. Revista San Gregorio, 37, $174-181$.

- MADDEN, D. (2008). Sample Selection Versus Two-Part Models Revisited: The Case of Female Smoking and Drinking. Journal of Health Economics, 27(2), 300-307.

- MARTIN, T. (2020). Smoking Statistics from Around the World. https://www.verywellmind.com/global-smokingstatistics-2824393. Accessed on June 8, 2021.

- MCMANUS, S., MELTZER, H. and CAMPION, J. (2010). Cigarette Smoking and Mental Health in England: Data from the Adult Psychiatric Morbidity Survey. National Centre for Social Research. Accessed on June 8, 2021.

- MUTLU ÇAMOĞLU, S. (2013). Türkiye'de Sigara Talebinin Analizi: İki aşamalı Heckman Süreci. EY International Congress on Economics I "Europe and Global Economic Rebalancing” October 24-25, 2013, Ankara/Turkey.

- NKOMO, Y.N., BEATRICE, D.S.K. and BIYASE, M. (2021). The Impact of Mental Health Behaviour on Tobacco Consumption in South Africa. EDWRG Working Paper Number 02-2021.

- OUR WORLD IN DATA (2021). https://ourworldindata.org/ Accessed on April 15, 2021.

- PIOLA, T.S., PACIFICO, A.B., CAMPOS, J.G., RIBEIRO, A.G., BACIL, E.D., SILVA, M.P. and CAMPOS, W. (2021). Cell Phone Use is Associated with Alcohol and Tobacco Consumption in Insufficiently Active Adolescents.The Journal of Sports Medicine and Physical Fitness, 61(3),444-451. doi: 10.23736/S0022-4707.20.11356-2.

- POLLAY, R. W., SIDDARTH, S., SIEGEL, M., HADDIX, A., MERRITT, R. K., GIOVINO, G. A. and ERIKSEN, M. 
P. (1996). The Last Straw? Cigarette Advertising and Realized Market Shares among Youths and Adults, 1979-1993. Journal of Marketing, 60(2), 1-16. https://doi.org/10.1177/002224299606000201.

- ROBERTSON, L., CAMERON, C., MCGEE, R., MARSH, L., and HOEK, J. (2016). Point-of-Sale Tobacco Promotion and Youth Smoking: A Meta-Analysis. Tobacco Control, 25(e2):e83-e9. Available from: https://www.ncbi.nlm.nih.gov/ pubmed/26728139.

- ROHDE, P., KAHLER, C.W., LEWINSOHN, P.M. and BROWN, R.A. (2004). Psychiatric Disorders, Familial Factors, and Cigarette Smoking: II. Associations with Progression to Daily Smoking. Nicotine \& Tobacco Research, 6, 119-32.

- IBARRA-SALAZAR, J., ROMERO-ROJAS, J.C. and AYALA-GAYTÁN, E. (2020). The Duration Effect of Pictorial Health Warnings on Tobacco Consumption in Mexico. Global Public Health, DOI: 10.1080/17441692.2020.1839928

- THE TOBACCO ATLAS (2021). http://files.tobaccoatlas.org/wp-content/uploads/pdf/kyrgyzstan-country-facts-en. pdf. Accessed on April 25, 2021.

- UNDP (2019). National Tobacco Control Strategies, file:///C:/Users/usre/Downloads/National_Tobacco_Control_ Strategies_Toolkit.pdf. Accessed on June 8, 2021.

- US DEPARTMENT OF HEALTH AND HUMAN SERVICES (2017). Preventing Tobacco Use Among Youths, Surgeon General fact sheet 2017. https://www.hhs.gov/surgeongeneral/reports-and-publications/tobacco/preventingyouth-tobacco-use-factsheet/index.html Accessed on April 25, 2021.

- US DEPARTMENT OF HEALTH AND HUMAN SERVICES (2014). The Health Consequences of Smoking --- 50 Years of Progress: A Report of the Surgeon General. 2014. Accessed on June 8, 2021.

- VINNIKOV, D., LAHDENSUO, A. and BRIMKULOV, N. (2006). Medical Students of Kyrgyzstan: Smoking Prevalence and Attitudes to Smoking Cessation Counseling. Global Heart, 2(1), 31-37. DOI: http://doi.org/10.1016/j. precon.2006.07.002

- WOOLDRIDGE, J.M. (2002). Econometric Analysis of Cross Section and Panel Data. Cambridge, MA: MIT Press.

- WHO (2018). Consumption and Approaches to the Regulation of Nasvay in the Commonwealth of Independent States. https://www.euro.who.int/_data/assets/pdf_file/0010/391762/Consumption-and-approaches-to-the-regulation-ofnasvay-in-CIS EN.pdf. Accessed on April 20, 2021.

- WORLD BANK (2020). https://data.worldbank.org/indicator/SH.PRV.SMOK?locations=KG. Accessed on April 15, 2021.

- YEN, S. T. (2005). Zero Observations and Gender Differences in Cigarette Consumption. Applied Economics, 37(16), 1839-1849, doi: 10.1080/00036840500214322

- ZUZANA, S., SONIA, I. and CRISTINA, S. (2018). Understanding the Drivers for Natura 2000 Payments in Forests: A Heckman Selection Analysis. Journal for Nature Conservation, 46, 28-37. https://doi.org/10.1016/j.jnc.2018.07.003. 